\title{
PERBANDINGAN PREMI ASURANSI KESEHATAN PESERTA BPJS BADAN USAHA DENGAN ASURANSI KESEHATAN SWASTA
}

\author{
Maya Widyana Dewi \\ STIE AAS Surakarta \\ Email : widyamine77@gmail.com \\ Devi Sulistyani \\ STIE AAS Surakarta \\ Email : devi_sulistyani46@yahoo.co.id
}

\begin{abstract}
ABSTRAK
BPJS adalah badan hukum yang berfungsi menyelenggarakan program jaminan kesehatan bagi seluruh masyarakat Indonesia termasuk warga asing yang bekerja paling singkat 6 bulan di Indonesia. Jaminan kesehatan ini berupa perlindungan kesehatan agar peserta memeperoleh manfaat pemeliharaan kesehatan dan perlindungan dalam memenuhi kebutuhan dasar kesehatan yang diberikan kepada setiap orang yang telah membayar iuran atau iurannya dibayar oleh pemerintah

Sumber data yang digunakan adalah data primer yang diperoleh dari penelusuran lapangan di BPJS Kesehatan cabang Surakarta dan data sekunder berupa pengumpulan data yang berupa data ataupun buku sumber dari kantor BPJS cabang Surakarta maupun dari sumber-sumber terpercaya lainnya. Teknik pengumpulan data yang digunakan adalah dengan menggunakan metode wawancara, observasi dan survey.

Penelitian ini lebih tertuju pada penelitian komparatif yaitu penelitian yang bersifat membandingkan, dalam hal ini adalah membandingkan hasil perhitungan premi asuransi BPJS badan usaha dengan premi asuransi kesehatan swasta, dimana hasilnya akan diturunkan untuk melihat adanya kelebihan dan kekurangan masing-masing.

Hasil perbandingan perhitungan premi asuransi kesehatan BPJS badan usaha dan asuransi kesehatan swasta menghasilkan premi asuransi kesehatan BPJS badan usaha yang jauh lebih murah daripada premi asuransi kesehatan swasta. Dengan adanya perhitungan premi yang demikian akan menjelaskan lebih lanjut tentang kelebihan dan kekurangan diantara asuransi kesehatan BPJS badan usaha dengan asuransi kesehatan swasta.
\end{abstract}

Kata kunci : jaminan kesehatan, premi asuransi kesehatan, BPJS, badan usaha, BPJS badan usaha dan asuransi kesehatan swasta 


\section{PENDAHULUAN}

Pemerintah Indonesia hingga kini belum mampu mewujudkan tercapainya cakupan peserta program jaminan sosial bagi seluruh penduduk Indonesia (universal coverage) (Mukti\&Moertjahjo, 2010). Hal ini berdasarkan data bahwa sekitar 37\% (87 juta) dari penduduk Indonesia belum memiliki atau tercover asuransi/jaminan kesehatan. Salah satu upaya pemerintah dalam hal universal coverage di mana semua warga berhak mendapatkan jaminan kesehatan, pada tahun 2004 telah menetapkan Undang- Undang Nomor 40 Tahun 2004 tentang Sistem Jaminan Sosial Nasional (SJSN). Dalam undang-undang ini ditegaskan bahwa jaminan kesehatan merupakan program jaminan sosial yang menjadi prioritas untuk diimplementasikan. Penetapan undang-undang ini merupakan salah satu wujud nyata komitmen penyelenggara Negara untuk menjalankan amanat konstitusi Undang-Undang Dasar 1945.

Tindak lanjut dari Undang-Undang No 40 Tahun 2004, dikeluarkanlah UU No 24 Tahun 2011 tentang Badan Penyelenggara Jaminan Sosial (BPJS), BPJS sebagaimana dimaksud pada pasal 5 ayat (1) adalah BPJS Kesehatan dan BPJS Ketenagakerjaan. BPJS bidang kesehatan sudah mulai berjalan 1 Januari 2014 dan BPJS Ketenaga kerjaan berjalan pada Juli 2015. Dalam melaksanakan UU SJSN dan UU BPJS perlu adanya perangkat peraturan pendukung. Namun, sampai Januari 2013, Pemerintah baru mengeluarkan satu peraturan Presiden yang mendukung pelaksanaan UU SJSN ini yaitu Peraturan Presiden No 12 Tahun
2013 Tentang Jaminan Kesehatan. Perangkat pendukung tidak mudah disusun oleh pemerintah dikarenakan perdebatan dari berbagai pihak yang belum memberikan hasil kesepakatan dalam hal ini mengenai masalah besaran iuran.

Adapun besarnya iuran premi BPJS Kesehatan tersebut tergantung pada fasilitas kesehatan yang nantinya hendak diakses oleh peserta. Sebagian besar pekerja buruh yang masuk dalam jaminan kesehatan milik PT Askes (Persero) dan PT Jamsostek (Persero) menginginkan pembayaran iuran BPJS yang serendah-rendahnya (Ariyanti, 2013).

Perhitungan premi program pemeliharaan kesehatan pada pelaksanaan BPJS Kesehatan ke depan basisnya mengikuti perhitungan asuransi sosial. Menurut Thabrany (2011), perhitungan iuran asuransi social tidak didasarkan atas tingkat angka kesakitan melainkan atas dasar prosentase upah. Perhitungan besaran iuran premi berdasarkan prosentase pendapatan/upah merupakan wujud pemerataan (equity) dan solidaritas social sekaligus fungsi pengaturan dan pengayoman pemerintah terhadap penduduk yang pendapatannya rendah (Samba, 2006).

Hasil penelitian yang dilakukan oleh (Iwanet al, 2008) mengemukakan bagaimana pentingnya sebuah premi/iuran dengan memperhitungkan beberapa aspek terkait dengan premi rill, premi utilisasi normative dan benefit paket dengan mempertimbangkan kemampuan dan kemauan membayar masyarakat. Hasil temuannya menyatakan bahwa jika jumlah kebutuhan dana untuk menanggulangi klaim terus meningkat dan 
tidak diimbangi dengan konsekuensi pembayaran premi yang sesuai maka beban badan penyelenggara/asuradur akan semakin besar.

Berdasarkan Peraturan Presiden No 12 Tahun 2013 Tentang Jaminan Kesehatan, BPJS Kesehatan menghitung kelebihan dan kekurangan iuran/premi sesuai dengan gaji atau upah peserta. Iuran/premi bagi peserta non PBI atau peserta pekerja penerima upah dibayar oleh pemberi kerja dan pekerja.Berbeda dengan perpres ini, JPK PT Jamsostek yang pada 1 Januari 2014 akan bergabung dengan BPJS Kesehatan, penyelenggaraan penarikan iuran sepenuhnya dibayarkan oleh pengusaha/pemberi kerja.

Umumnya peserta mengharapkan (menuntut) pelayanan yang lebih baik dari suatu system asuransi/jaminan kesehatan.Kalau premi terlalu rendah akibatnya pembayaran kepada PPK (Penyedia Pelayanan Kesehatan) juga rendah dana kan sulit bagi PPK melakukanpeningkatanmutupelayanan (Ganiet al.,2008). Pembayaran kepada PPK selama dua decade terakhir dalam skema asuransi kesehatan di Indonesia telah menggunakan system pembayaran kapitasi(Hendrartini, 2008). Dengan pembayaran kapitasi yang diberikan secarapraupaya, diharapkan PPK dapat merencanakan efisiensi program dengan lebih baik (Hendrartini,2010).Namun hal ini akan berbeda, jika rasio pendapatan dari pembayaran kapitasi masih rendah maka pembayaran kapitasi tidak efektif untuk mengubah kinerja dokter.

Dari latar belakang permasalahan di atas, maka dirumuskan permasalahan yaitu bagaimana perhitungan premi asuransi kesehatan BPJS badan usaha dan perhitungan premi asuransi kesehatan swasta. Dari perbedaan perhitungan premi bulanan akan diturunkan lagi tentang apakah kelebihan dan kelemahan asuransi BPJS badan usaha dengan asuransi kesehatan swasta

\section{KAJIAN PUSTAKA}

\section{Jaminan Sosial}

Jaminan Sosial (social security) merupakan bagian dari konsep perlindungan sosial (social protection), dimana perlindungan social sifatnya lebih luas. Perbedaan keduanya adalah bahwa jaminan sosial memberikan perlindungan sosial bagi individu dengan dana yang diperoleh dari iuran berkala, sedangkan perlindungan sosial biasanya melibatkan banyak pihak dalam memberikan perlindungan baik kepada individu, keluaraga atau komunitas dari berbagai risiko kehidupan yang tidak dapat dipredksi sebelumnya seperti krisis ekonomi, atau bencana alam. Hal tersebut sejalan dengan pendapat BAPPENAS yang telah mengadakan kajian awal tentang Sistem Jaminan Sosial Nasional (SJSN), dan dalam kajian tersebut dikemukakan pendapat bahwa jaminan social mencakup dua hal yaitu :

1. Asuransi Sosial (Social Insurance)

Asuransi Sosial mempunyai konsep sebagaimana asuransi pada umumnya, dimana pembayaran premi menjadi tanggungan bersama antara pemberi kerja (yaitu pemerintah dan pengusaha) dan pekerja (Pegawai Negeri Sipil (PNS), ABRI/POLRI atau Pegawai Swasta) oleh karena adanya hubungan kerja. Menurut Undang-Undang Nomor 40 Tahun 2004 tentang SJSN, definisi Asuransi Sosial adalah sebagaimana yang 
dinyatakan dalam Pasal 1 ayat 3 yaitu suatu mekanisme pengumpulan dana yang bersifat wajib yang berasal dari iuran guna memberikan perlindungan atas risiko sosial ekonomi yang menimpa peserta dan/atau anggota keluarganya.

2. Bantuan Sosial

Bantuan Sosial berupa 'bantuan' dalam berbagai bentuk, uang, jasa maupun barang dengan tujuan sosial.

\section{Sistem Jaminan Sosial Nasional (SJSN)}

Sistem Jaminan Sosial Nasional adalah sistem penyelenggaraan program negara dan pemerintah untuk memberikan perlindungan sosial, agar setiap penduduk dapat memenuhi kebutuhan dasar hidup yang layak, menuju terwujudnya kesejahteraan sosial bagi seluruh penduduk Indonesia. Jaminan social diperlukan apabila terjadi hal-hal yang tidak dikehendaki yang dapat mengakibatkan hilangnya atau berkurangnya pendapatan seseorang, baik karena memasuki usia lanjut atau pensiun, maupun karena gangguan kesehatan, cacat, kehilangan pekerjaan dan lain sebagainya.

\section{Jaminan Kesehatan Nasional}

JKN merupakan program pelayanan kesehatan terbaru yang merupakan kepanjangan dari Jaminan Kesehatan Nasional yang sistemnya menggunakan sistem asuransi. Artinya, seluruh warga Indonesia nantinya wajib menyisihkan sebagian kecil uangnya untuk jaminan kesehatan di masa depan.

\section{BPJS}

Badan Penyelenggara Jaminan Sosial (BPJS) adalah badan hukum yang berfungsi menyelenggarakan program jaminan kesehatan bagi seluruh masyarakat indonesia termasuk warga asing yang bekerja paling singkat 6 bulan di indonesia.Peserta BPJS terdiri dari bantuan iuran (PBI) yang terdiri dari fakir miskin serta orang tidak mampu,dan golongan non PBI /Peserta dari peralihan Askes (UU BPJS 2011).

UU Nomor 24 Tahun 2011 tentang BPJS membentuk 2 Badan Penyelenggara Jaminan Sosial yaitu BPJS Kesehatan dan BPJS Ketenagakerjaan.

1. BPJS Kesehatan

BPJS Kesehatan adalah badan hukum publik yang bertanggung jawab kepada presiden dan berfungsi menyelenggarakan program jaminan kesehatan.

Jaminan Kesehatan adalah jaminan berupa perlindungan kesehatan agar peserta memperoleh manfaat pemeliharaan kesehatan dan perlindungan dalam memenuhi kebutuhan dasar kesehatan yang diberikan kepada setiap orang yang telah membayar iuran atau iurannya dibayar oleh pemerintah. BPJS Kesehatan diselenggarakan pada tangal 1 Januari 2014 sesuai dengan UU BPJS.

2. BPJS Ketenagakerjaan

BPJS Ketenagakerjaan adalah badan hukum publik yang bertanggung jawab kepada presiden dan berfungsi menyelenggarakan program jaminan kecelakaan kerja, jaminan hari tua, jaminan pensiun dan jaminnan kematian.

Pada tanggal 1 Januari 2014, pemerintah mengubah PT.Jamsostek (Persero) menjadi BPJS Ketenagakerjaan atas perintah UU BPJS.

\section{Badan Usaha}

Badan Usaha adalah kesatuan yuridis dan ekonomis dari faktor-faktor produksi yang bertujuan mencari laba atau memberi layanan 
kepada masyarakat. Disebut kesatuan yuridis karena badan usaha umumnya berbadan hukum. Disebut kesatuan ekonomis karena faktor-faktor produksi badan usaha terdiri atas sumber daya alam, modal, dan tenaga kerja dikombinasikan untuk mendapat laba atau member layanan kepada masyarakat.

Pekerja adalah setiap orang yang bekerja dengan menerima gaji, upah,atau imbalan dalam bentuk lain.

Pemberi Kerja adalah orang perseorangan, pengusaha, badan hukum, atau badan lainnya yang mempekerjakan tenaga kerja, atau penyelenggaranegara yang mempekerjakan pegawai negeri dengan membayar gaji, upah, atau imbalan dalam bentuk lainnya.

\section{BPJS Badan Usaha}

Setiap perusahaan wajib mendaftarkan pekerjaanya sebagai anggota BPJS. Sedangkan orang atau keluarga yang tidak bekerja pada perusahaan wajib mendaftarkan diri dan anggota keluarganya pada BPJS. Setiap peserta BPJS akan ditarik iuran yang besarnya ditentukan kemudian. Sedangkan bagi warga miskin, iuran BPJS ditanggung pemerintah melalui Program Bantuan Iuran.

Menjadi peserta BPJS tidak hanya wajib bagi pekerja di sektor formal, namun juga pekerja informal. Pekerjaan informal juga wajib menjadi anggota BPJS Kesehatan. Para pekerja wajib mendaftarkan dirinya dan membayar iuran sesuai dengan tingkatan manfaat yang diinginkan.

\section{Premi}

Dalam bahasa Inggris premi berarti premium yaitu uang angsuran kepada perusahaan asuransi,sedangkan menurut Kamus Besar Bahasa Indonesia premi adalah uang yang harus dibayarkan pada waktu tertentu oleh yang akan memperoleh ganti rugi.

Ada beberapa pengertian premi sebagai berikut:

1. Seperti yang dikemukakan oleh Afzalur Rahman(1996), premi adalah suatu harga yang ditetapkan perusahaan asuransi untuk mengambil alih risiko dan memikul beban kemungkinan risiko kerugian sebagaimana disepakati dalam kontrak asuransi.

2. Menurut

Muhammad

Muslehudin(1999)bahwa premi adalah upah asuransi atau harga yang dipungut oleh pihak penjamin agar dapat melaksanakan kewajibannya.

3. Sedangkan Abdul Kadir Muhammad(1999) berpendapat premi itu adalah sejumlah uang yang wajib dibayar oleh tertanggung kepada penanggung setiap jangka waktu tertentu,biasanya setiap bulan selama asuransi berlangsung.

\section{Fungsi Premi}

Adapun fungsi dari premi yaitu:

1. Mengembalikan tertanggung pada posisi ekonomi seperti sebelum terjadi kerugian.

2. Mengembalikan tertanggung dari kebangkrutan, hingga mampu berdiri pada posisi seperti keadaan sebelum terjadi kerugian

3. Harga pembelian dari tanggungan yang wajib diberikan oleh penanggung atau sebagai imbalan resiko yang diperalihkan pertanggungan dibuat, kecuali pertanggungan saling menanggung.

\section{Klaim}

Klaim dalam kamus asuransi adalah permohonan atau tuntutan seorang pemilik polis terhadap perusahaan asuransi untuk pembayaran santunan sesuai dengan pasalpasal dari sebuah polis. 


\section{Asuransi}

Asuransi pada dasarnya adalah suatu sistem manajemen resiko, dimana kepada pesertanya (tertanggung/pemegang polis) ditawarkan kesempatan untuk secara bersama-sama menanggung kerugian ekonomi yang mungkin timbul, dengan cara membayar premi kepada perusahaan asuransi.

\section{Premi Asuransi Kesehatan}

Angsuran yang dibayarkan kepada perusahaan asuransi sebagai konsekuensi dari pemakaian sebuah jenis produk asuransi yang menjamin biaya kesehatan atau perawatan para peserta asuransi jika mereka sakit atau mengalami kecelakaan

\section{Asuransi Kesehatan Swasta}

Asuransi Kesehatan Swasta adalah asuransi yang dapat memberikan pertanggungan terhadap asuransi jiwa, asuransi kebakaran dan asuransi kecelakaan. Asuransi Swasta kepesertaanya bersifat sukarela dan biasanya dikelola oleh badan usaha swasta yang bertujuan untuk mencari keuntungan.

\section{HASIL PENELITIAN DAN}

\section{PEMBAHASAN}

\section{A. Kepesertaan BPJS Kesehatan}

Peserta adalah setiap orang, termasuk orang asing yang bekerja paling singkat 6 (enam) bulan di Indonesia, yang telah membayar iuran.

Kepesertaan BPJS Kesehatan adalah sebagai betikut:

1. Jumlah peserta dan anggota keluarga inti yang ditanggung oleh jaminan kesehatan paling banyak 5(lima) orang, meliputi :

a) Istri atau suami yang sah dari peserta, dan b) Anak kandung, anak tiri dan/atau anak angkat yang sah dari peserta, dengan kriteria:

1) Tidak atau belum pernah menikah atau tidak mempunyai penghasilan sendiri, dan

2) Belum berusia 21 tahun atau belum berusia 25 tahun yang masih melanjutkan pendidikan formal.

2. Peserta yang memiliki jumlah keluarga lebih dari 5 (lima) orang termasuk peserta, dapat mengikut sertakan anggota keluarganya yang lain dengan membayar iuran tambahan.

Anggota keluarga tambahan meliputi:

a) Anak kandung, anak tiri dan/atau anak angkat yang sah dari peserta

b) Orang tua

c) Mertua

\section{B. Hak dan Kewajiban Peserta BPJS Kesehatan}

1. Hak Peserta

a) Mendapatkan kartu peserta sebagai bukti sah untuk memperoleh pelayanan kesehatan

b) Memperoleh manfaat dan informasi tentang hak dan kewajiban serta prosedur pelayanan kesehatan sesuai dengan ketentuan yang berlaku

c) Mendapatkan pelayanan kesehatan di fasilitas kesehatan yang bekerja sama dengan BPJS Kesehatan,dan

d) Menyampaikan keluhan /pengaduan ,kritik dan saran secara lisan atau tertulis ke kantor BPJS Kesehatan.

2. Kewajiban Peserta

a) Mendaftarkan dirinya sebagai peserta serta membayar iuran yang besarnya sesuai dengan ketentuan yang berlaku 
b) Melaporkan perubahan data peserta, baik karena pernikahan, perceraian, kematian, kelahiran,pindah alamat atau pindah fasilitas kesehatan tingkat I

c) Menjaga Kartu Peserta agar tidak rusak, hilang atau dimanfaatkan oleh orang yang tidak berhak

d) Mentaati semua ketentuan dan tata cara pelayanan kesehatan.

\section{Perhitungan Premi BPJS Kesehatan}

Premi adalah uang yang harus dibayarkan pada waktu tertentu oleh yang akan memperoleh ganti rugi.

Untuk mengikuti BPJS Kesehatan maka peserta diwajibkan membayar iuran/premi kepada BPJS Kesehatan. Adapun besarnya iuran/premi BPJS Kesehatan tersebut tergantung pada fasilitas kesehatan yang nantinya hendak diakses oleh peserta. Adapun besaran premi BPJS Kesehatan dijelaskan seperti di bawah ini :

1. Bagi peserta Penerima Bantun Iuran (PBI) Jaminan Kesehatan iuran dibayar oleh Pemerintah.

2. Iuran bagi Peserta Pekerja Penerima Upah yang bekerja pada Lembaga Pemerintahan terdiri dari Pegawai Negeri Sipil, anggota TNI, anggota Polri, pejabat negara, dan pegawai pemerintah non pegawai negeri sebesar 5\% (lima persen) dari Gaji atau Upah per bulan dengan ketentuan : 3\% (tiga persen) dibayar oleh pemberi kerja dan 2\% (dua persen) dibayar oleh peserta.

3. Iuran bagi Peserta Pekerja Penerima Upah yang bekerja di BUMN, BUMD dan Swasta sebesar 4,5\% (empat koma lima persen) dari Gaji atau Upah per bulan dengan ketentuan : 4\% (empat persen) dibayar oleh Pemberi Kerja dan 0,5\% (nol koma lima persen) dibayar oleh Peserta.
4. Iuran untuk keluarga tambahan Pekerja Penerima Upah yang terdiri dari anak ke 4 dan seterusnya, ayah, ibu dan mertua, besaran iuran sebesar sebesar $1 \%$ (satu persen) dari gaji atau upah per orang per bulan, dibayar oleh pekerja penerima upah.

5. Iuran bagi kerabat lain dari pekerja penerima upah (seperti saudara kandung/ipar, asisten rumah tangga, dll), peserta pekerja bukan penerima upah serta iuran peserta bukan pekerja adalah sebesar:

a) Sebesar Rp.25.500,- (dua puluh lima ribu lima ratus rupiah) per orang per bulan dengan manfaat pelayanan di ruang perawatan Kelas III.

b) Sebesar Rp.42.500 (empat puluh dua ribu lima ratus rupiah) per orang per bulan dengan manfaat pelayanan di ruang perawatan Kelas II

c) Sebesar Rp.59.500,- (lima puluh sembilan ribu lima ratus rupiah) per orang per bulan dengan manfaat pelayanan di ruang perawatan Kelas I

6. Iuran Jaminan Kesehatan bagi Veteran, Perintis Kemerdekaan, dan janda, duda, atau anak yatim piatu dari Veteran atau Perintis Kemerdekaan, iurannya ditetapkan sebesar 5\% (lima persen) dari 45\% (empat puluh lima persen) gaji pokok Pegawai Negeri Sipil golongan ruang III/a dengan masa kerja 14 (empat belas) tahun per bulan, dibayar oleh Pemerintah.

7. Pembayaran iuran paling lambat tanggal 10 (sepuluh) setiap bulan

\section{Hak Kelas Perawatan Terhadap Besaran Iuran}

1. Kelas 1 bagi :

Peserta Pekerja Penerima Upah dan Pegawai Pemerintah Non Pegawai Negeri dengan gaji atau upah diatas 1,5 (satu koma lima) sampai 
dengan 2 (dua) kali PTKP dengan status kawin dengan 1 (satu) anak, beserta anggota keluarganya, dan

2. Kelas 2 bagi :

Peserta Pekerja Penerima Upah dan Pegawai Pemerintah Non Pegawai Negeri dengan gaji atau upah sampai dengan 1,5 (satu koma lima) kali PTKP dengan status kawin dengan 1 (satu) anak, beserta anggota keluarganya.

\section{E. Pengertian PTKP}

PTKP adalah pengurangan penghasilan neto bagi Waib Pajak Orang Pribadi dalam menentukan besarnya penghasilan kena pajak (PKP).PTKP ditentukan 1 Januari tahun pajak bersangkutan. PTKP sendiri dibedakan antara Wajib Pajak Kawin dan yang tidak kawin. Sehingga secara rinci besaran PTKP adalah sebagai berikut:

a. Rp. 24.300.000,- untuk Wajib Pajak Orang F. Pribadi

b. Rp. 2.025.000,- untuk tambahan Wajib Pajak yang Kawin

c. Rp. 24.300.000,- tambahan untuk seorang isteri yang penghasilannya digabung dengan penghasilan suami sebagaimana dimaksud dalam Pasal 8 ayat (1) UU PPh.

d. Rp. 2.025.000,- tambahan untuk setiap anggota keluarga sedarah dan keluarga semeda dalam garis keturunan lurus serta anak angkat, yang menjadi tanggungan sepenuhnya, paling banyak 3 (tiga) orang untuk setiap keluarga.

1. PTKP bagi Wajib Tidak Kawin

Bagi Wajib Pajak Tidak Kawin, maka status PTKP nya adalah TK/jumlah tanggungan (TK garis miring jumlah tanggungan). Misalnya Wajib Pajak bujangan yang tidak memiliki tanggungan, dituliskan sebagai TK/0 (dibaca Tidak Kawin 0 tanggungan). Wajib Pajak bujangan yang menanggung keluarga sedarah 1 orang akan dituliskan TK/1, dan seterusnya. Untuk menentukan PTKP Wajib Pajak yang tidak kawin relatif lebih mudah.

2. PTKP Wajib Pajak Kawin

Wajib Pajak yang telah kawin, selain mendapatkan PTKP untuk dirinya sendiri, juga mendapatkan PTKP untuk status perkawinannya, ditambah anggota keluarga yang menjadi tanggungan sepenuhnya maksimal 3 orang.

Premi Kesehatan karyawan yang ditanggung atau dibayarkan oleh perusahaan merupakan penghasilan bagi karyawan sehingga dikenakan PPh Pasal 21. Namun Premi Kesehatan yang ditanggung karyawan melalui pemotogan gaji bukan merupakan pengurang penghasilan karyawan dalam menghitung PPh Pasal 21.

\section{Cara menghitung premi BPJS sebagai berikut:}

1. Seorang tenaga administrasi di PT. Santosa, memiliki upah pokok sebesar Rp. 1.500.000,perbulan. Maka besarnya iuran/premi BPJS Kesehatan yang harus di bayar adalah :

1 Januari 2014 s/d 30 Juni 2015 :

Besar Iuran : 4,5 \% x (Upah Pokok + Tunjangan Tetap), 4\% dibayarkan PT. Santosa, $0.5 \%$ dibayarkan pegawai :

4\% x Rp. 1.500.000,- = Rp. 60.000,- (dibayar PT Santosa)

0.5\% x Rp. 1.500.000,- = Rp. 7.500,- (dibayar pegawai)

Mulai 1 Juli 2015 :

Besar Iuran : 5\% x (Upah Pokok + Tunjangan Tetap), 4\% dibayarkan PT. Santosa, $1 \%$ dibayarkan pegawai :

4\% x Rp. 1.500.000,- = Rp. 60.000,- (dibayar PT Santosa) 
$1 \%$ x Rp. 1.500.000,- = Rp. 15.000,- (dibayar pegawai)

Hak Perawatan di Kelas II, karena upah pokok sebesar Rp. 1.000.000,- per bulan termasuk kelompok penghasilan 0 s/d 1,5 X PTKP K1 (1X PTKP K1 = Rp. 2.362.500,-)

\section{G. Besaran Iuran Anggota Keluarga Lainnya}

Tambahan Anggota Keluarga dari Pekerja Penerima Upah(PPU):

a. Keluarga tambahan dari PPU terdiri dari anak ke 4 dan seterusnya, ayah, ibu dan mertua, besaran iuran sebesar 1\% dari gaji atau upah per orang per bulan.

b. Peserta tambahan lainya dari PPU seperti I. keponakan, kerabat lain, asisten rumah tangga dan lainnya,

\section{Cara menghitungnya sebagai berikut :}

1. Direktur Keuangan Perusahaan Cargo, memiliki upah pokok sebesar Rp. 15.000.000,per bulan dan tunjangan transportasi Rp. 5.000.000,- per bulan. Selain istri dan kedua anaknya, Direktur Keuangan ini juga ingin memasukkan kedua orang tua dan mertua nya (total 4 anggota keluarga tambahan) sebagai pesertaBPJS Kesehatan. Besar iuran BPJS Kesehatan yang harus di bayar adalah :

1 Januari 2014 s/d 30 Juni 2015 :

Besar Iuran Keluarga Inti : 4,5 \% x (Upah Pokok + Tunjangan Tetap),4\% dibayarkan Perusahaan Cargo Pasti Sampai, 0.5\% dibayarkan pegawai Besar Iuran Keluarga Tambahan : 1\% x (Upah Pokok + Tunjangan Tetap) per orang 4\% x Rp. 4.725.000,- = Rp. 189.000,- (dibayar Perusahaan Cargo Pasti Sampai)

$0.5 \%$ x Rp. 4.725.000,- = Rp. 23.625,(dibayar pegawai)

$1 \%$ x 4 orang $\times$ Rp. 4.725.000,- = Rp. 189.000,- (dibayar pegawai)
Mulai 1 Juli 2015 :

Besar Iuran : 5\% x (Upah Pokok + Tunjangan Tetap), 4\% dibayarkan Perusahaan Cargo Pasti Sampai, 1\%dibayarkan pegawai

Besar Iuran Keluarga Tambahan : 1\% x (Upah Pokok + Tunjangan Tetap) per orang 4\% x Rp. 4.725.000,- = Rp. 189.000,- (dibayar Perusahaan Cargo Pasti Sampai)

1\% x Rp. 4.725.000,- = Rp. 47.250,- (dibayar pegawai)

$1 \%$ x 4 orang $\times$ Rp. 4.725.000,- = Rp. 189.000,- (dibayar pegawai)

H.

\section{Perbandingan BPJS dengan Asuransi Swasta}

Asuransi menurut Undang-Undang Republik Indonesia Nomor 2 tahun 1992 adalah perjanjian antara dua pihak atau lebih dengan mana pihak penanggung mengikatkan diri kepada tertanggung, dengan menerima premi asuransi, untuk memberikan penggantian kepada tertanggung karena kerugian, kerusakan atau kehilangan keuntungan yang diharapkan, atau tanggung jawab hukum pihak ketiga yang mungkin akan diderita tertanggung, yang timbul dari suatu peristiwa yang tidak pasti, atau untuk memberikan suatu pembayaran yang didasarkan atas meninggal atau hidupnya seseorang yang dipertanggungkan.

1. Jenis Pengelolaan Asuransi

Berdasarkan jenis pengelolaannya maka asuransi dibagi menjadi dua kelompok yaitu:

a. Asuransi Sosial

Jenis asuransi ini dikelola oleh pemerintah atau BUMN dengan tujuan memberika suatu tingkat jaminan tertentu kepada seseorang atau kelompok yang mampu maupun tidak mampu menjadikan jaminan termaksud bagi dirinya.

Menurut UU No.2 tahun 1992, disebutkan bahwa program asuransi sosial adalah program 
asuransi yang diselenggarakan secara wajib berdasrkan suatu UU dengan tujuan memberikan perlindungan dasar bagi kesejahteraan masyarakat. Dalam UU ini disebutkan bahwa program asuransi sosial hanya dapat dilaksanakan oleh Badan Usaha Milik Negara (BUMN) contohnya Badan Penyelenggara Jaminan Sosial ( BPJS).

b. Asuransi Komersial

Asuransi komersial berbasis kepada kepesertaan sukarela dan biasanya dikelola oleh badan usaha swasta yang bertujuan untuk mencari keuntungan .

Pada asuransi Komersial, pihak asuransi bertindak sebagai pedagang yang menawarkan paket asuransi kepada masyarakat sebagai calon pembeli. Jika paket yang ditawarka sesuai dengan apa yang diperluka masyarakat, maka paket tersebut akan dibeli dalam jumlah besar sehingga pihak pedagang akan memperoleh laba yang besar pula. Namun sebaliknya, jika paket tersebut tidak diminati masyarakat maka akan sendirinya tidak akan laku dan nantinya akan menyebabkan kerugian bagi pihak asuransi/pedagang, contohnya asuransi prudential.

Inilah yang membedakan sistem asuransi sosial dengan asuransi komersial. Asuransi sosial merespond need (kebutuhan) sedangkan asuransi komersial merespon demand (permintaan).Tujuan asuransi komersial ini adalah untuk memenuhi permintaan peroreangan yang berbeda-beda.

Perbedaan prinsip Asuransi Sosial dan Asuransi Komersial

\begin{tabular}{|c|c|c|}
\hline Aspek & Asuransi Sosial & Asuransi Komersial \\
\hline Kepesertaan & Wajib & Sukarela \\
\hline $\begin{array}{l}\text { Sifat gotong royong antar } \\
\text { golongan }\end{array}$ & $\begin{array}{l}\text { Muda-Tua } \\
\text { Kaya-Miskin } \\
\text { Sehat-Sakit }\end{array}$ & Sehat-Sakit \\
\hline Premi & $\begin{array}{l}\text { Biasanya proposional } \\
\text { terhadap upah }\end{array}$ & $\begin{array}{ll}\text { Biasanya } & \text { dalam } \\
\text { jumlah } & \text { harga } \\
\text { tertentu } & \end{array}$ \\
\hline Paket jaminan/benefit & $\begin{array}{l}\text { Sama untuk semua } \\
\text { peserta }\end{array}$ & $\begin{array}{l}\text { Bervariasi sesuai } \\
\text { dengan premi yang } \\
\text { dibayar }\end{array}$ \\
\hline Keadilan & Sosial & Individual \\
\hline Respon pelayanan medis & $\begin{array}{l}\text { Pemenuhan kebutuhan } \\
\text { medis }\end{array}$ & $\begin{array}{l}\text { Pemenuhan } \\
\text { Permintaan medis }\end{array}$ \\
\hline
\end{tabular}

\section{Perhitungan asuransi prudential (Human Life Value)}

Suatu keluarga dengan ayah Budi berusia 35 tahun memiliki seorang isteri yang tidak bekerja dan seorang anak yang berusia lima tahun. Penghasilan si ayah 4 juta per bulan. Maka berdasarkan metode human life value, uang pertanggungan asuransi yang diperlukan adalah sebesar Rp. 4 juta $\times 12$ × 20 tahun=Rp 960 juta. Mengapa dikalikan dengan 20 tahun ? 
waktu 20 tahun itulah merupakan mas yang harus dilindungi. Mengingat si anak saat ini berusia 5 tahun, dalam waktu 20 tahun mendatang dia akan berusia 25 tahun, diharapkan sudah selesai kuliah dan dapat membiayai dirinya sendiri sehingga tidak tergantung lagi dari uang pertanggungan asuransi. Sehingga keluarga ini memerlukan uang pertanggungan asuransi sebesar Rp. 1,2 milyar untuk memproteksi keperluan keluarga selama 20 tahun. Semakin tinggi pertanggungan, semakin tinggi pula premi yang harus dibayarkan.

\section{J. Kelebihan dan Kekurangan BPJS}

1. Kelebihan BPJS Kesehatan

a) Premi Murah

Premi BPJS ditentukan berdasarkan kelas yang diambil, tidak membedakan usia dan jenis kelamin. Premi BPJS Kesehatan per bulan adalah sebagai berikut:

1. Kelas 1:59.500

2. Kelas 2:42.500

3. Kelas 3:25.500

Jika kita membandingkan dengan asuransi kesehatan swasta yang besarnya sekitar 300500 ribu perbulan, premi BPJS Kesehatan amat sangat murah. Selain itu BPJS Kesehatan tidak membedakan peserta merokok atau tidak.

b) Manfaat kesehatan yang dijamin Selain murah, manfaat yang diberikan BPJS Kesehatan juga lebih lengkap dari asuransi kesehatan swasta. Berikut manfaat yang diberikan BPJS:

1. Rawat Inap

2. Rawat Jalan

3. Kehamilan, melahirkan dan persalinan dengan operasi caesar

4. Optik/Kacamata.

c) Tidak ada Pre-Existing Condition
BPJS Kesehatan tidak memberlakukan preexisting condition, yaitu kondisi sakit yang pernah diderita peserta. BPJS menanggung semua penyakit termasuk penyakit yang sudah pernah ada sebelum peserta bergabuing, untuk itu tidak diperlukan medical check up apabila ingin menjadi peserta BPJS Kesehatan.

d) Full Cashless

Peserta tidak perlu membayar selama mengikuti kelas kamar yang sesuai dengan premi yang diambil. Apabila kelas kamar penuh dan melakukan upgrade kelas, maka kelebihan biaya itu yang harus dibayar peserta BPJS Kesehatan.

e) Tidak ada batasan Plafond

Tiap produk asuransi kesehatan pasti memiliki plafond atau batasan pertanggungan, misalnya biaya kamar per malam maksimal 500 ribu, biaya operasi dan dokter 10 juta. Jika biaya rumah sakit melebihi plafond yang sudah ditentukan, maka kelebihan tersebut tidak akan diganti oleh asuransi.

BPJS Kesehatan merujuk pada buku panduan, tidak ada plafond atau batasan biaya penggantian. Selama mengikuti prosedur dan menggunakan kelas kamar yang ditentukan, semua biaya penggobatan ditanggung oleh BPJS.

2. Kekurangan BPJS Kesehatan

a) Prosesnya Panjang dan Kurang Fleksibel BPJS Kesehatan memberlakukan sistem rujukan berjenjang yaitu peserta tidak bisa langsung datang ke rumah sakit tetapi harus datang dahulu ke fasilitas kesehatan (faskes) tingkat 1 yaitu puskesmas, klinik atau dokter keluarga yang sudah ditunjuk BPJS.Jika ada keputusan dari faskes tingkat 1 untuk melakukan rujukan di rumah sakit, peserta dibolehkan langsung ke rumah sakit namun 
tidak bisa menentukan ingin dirawat di rumah sakit mana.

Berbeda dengan asuransi swasta, proses ini tidak akan ditemui. Peserta bisa langsung ke rumah sakit manapun dan tinggal menunjukan kartu cashless atau reimburse apabila rumah sakit bukan rumah sakit rekanan.

b) Antrian yang Panjang

Karena premi yang murah dan dijamin oleh pemerintah, peserta BPJS Kesehatan sangatlah banyak dan terkadang fasilitas kesehatan dan rumah sakit tidak mampu melayani sehingga terjadi antrian. Aakan menjadi masalah apabila keadaan darurat dan harus dirawat saat itu juga.

c) Tidak Semua Rumah Sakit Bekerjasama dengan BPJS Kesehatan

Tidak semua rumah sakit bekerja sama dengan BPJS Kesehatan terutama rumah sakit swasta karena belum bekerjasama dengan BPJS. Apabila tidak bekerjasama, peserta tidak bisa menggunakan manfaat keanggotaannya di BPJS Kesehatan. Kebanyakan rumah sakit swasta yang bekerjasama pun tergolong rumah sakit kelas C yang fasilitasnya kurang memadai.

d) Biaya Rumah Sakit yang tidak diganti

Ini kondisi yang banyak dikeluhkan peserta BPJS, yaitu penggantian tidak penuh meskipun sudah mengikuti ketentuan kelas kamar, atau penggantian obat dilakukan secara bertahap (tidak sekaligus).

Berbeda dengan asuransi kesehatan, BPJS tidak mengenal plafond.Jadi, dengan pihak rumah sakit, BPJS sudah sepakat di awal mengenai besaran tariff berdasarkan pada diagnose penyakit dan ketentuan tindakan serta obat yang mesti digunakan. Besaran tariff tetap, apapun dan berapapun tindakan medis yang dilakukan.Sistem ini disebut dengan INA CBGs.

Dengan metode INA CBGs, beban BPJS menjadi lebih predictable. Namun, untuk rumah sakit itu bias menjadi boomerang karena mungkin actual cost-nya berbeda dengan perhitungan INA CBGs.

\section{Perbandinganantara BPJS denganAsuransi Kesehatan Swasta}

\begin{tabular}{|l|c|c|}
\hline & BPJS & ASURANSI \\
& KESEHATAN SWASTA \\
\hline Premi & Murah & Mahal \\
\hline Manfaat & $\begin{array}{c}\text { Lengkap (RawatJalan, } \\
\text { Inap, Gigi\&Optik) }\end{array}$ & Terbatas (RawatInap) \\
\hline Syarat & Mudah & LebihSulit \\
\hline Plafond & Tidakada & Ada \\
\hline Proses & Rumit & Sederhana \\
\hline RumahSakit & Terbatas RS & Semua RS \\
\hline Double-Claim & Tidakada & Bisa \\
\hline LuarNegeri & Tidakada & Bisa \\
\hline
\end{tabular}


Dengan perbandingan di atas apakah asuransi kesehatan swastaakan ditinggalkan? Ternyata tidak, masing-masing memiliki kelebihan sendiri-sendiri. BPJS dan asuransi kesehatan swasta akan berjalan beriringan dan tidak saling mematikan, justru ini bagus untuk kita masyarakat karena mempunyai lebih banyak pilihan untuk mempercayakan jaminan kesehatannya.

\section{K. Kelebihan dan Kekurangan Asuransi Kesehatan Swasta}

1. Kelebihan Asuransi Kesehatan Swasta

a) Pihak penyelenggara tidak terbatas

b) Memiliki Plafond

c) Prosesnya sangat sederhana

d) Semua rumah sakit melayani

e) Bisa digunakan di luar negeri

2. Kekurangan Asuransi Kesehatan Swasta

a) Besarnya premi tinggi

b) Kepesertaan bersifat sukarela sehingga kepesertaan sangat sedikit

c) Biaya administrasi mahal

d) Memiliki administrasi yang rumit

e) Ruang inap sangat terbatas

f) Syarat untuk memiliki asuransi kesehatan swasta sangat sulit

Harus disadari bahwa tidak ada sistem pembiayaan kesehatan yang sempurna, masingmasing mempunyai kelebihan dan kekurangan. Namun, sistem ekonomi pasar yang bergerak bebas tanpa aturan harus diatur dalam sebuah sistem pembiayaan kesehatan yang komprehensif, yang dapat mengurangi kemungkinan dampak buruk hubungan penyedia dan pencari layanan kesehatan. Walaupun berat dan kompleks, sedikit demi sedikit hal ini harus dapat diwujudkan untuk dapat meningkatkan derajat kesehatan masyarakat Indonesia secara efektif dan efisien.

\section{KESIMPULAN DAN SARAN}

\section{A. KESIMPULAN}

BPJS Kesehatan adalah badan hukum yang dibentuk untuk menyelenggarakan program jaminan sosial dan kesehatan untuk seluruh masyarakat Indonesia, karena setiap individu berhak untuk hidup, baik itu masyarakat yang kaya atau masyarakat yang kurang dalam perekonomiannya.

Manfaat jaminan Kesehatan adalah sebagai berikut :

1) Bersifat pelayanan kesehatan perorangan, mencakup pelayanan promotif, prefentif, kuratif, rehabilitatif, pelayanan obat, bahan medis habis pakai sesuai dengan indikasi medis yang diperlukan.

2) Manfaat medis yang tidak terikat dengan besaran iuran yang dibayarkan, manfaat non medis yang ditentukan berdasarkan skala besaran iuran yang dibayarkan, termasuk didalamnya manfaat akomodasi.

3) Ambulans diberikan untuk pasien rujukan dari fasilitas kesehatan dengan kondisi tertentu yang ditetapkan oleh BPJS Kesehatan.

Kesimpulan yang dapat ditarik perbandingan dan pembahasan yang sudah dilakukan adalah :

a. Perhitungan premi BPJS Kesehatan Badan Usaha dihitung berdasarkan proporsi terhadap upah.

b. Kelebihan dan Kekurangan BPJS Kesehatan

1) Kelebihan BPJS Kesehatan meliputi :

a. Premi Murah

b. Manfaat Kesehatan yang dijamin

c. Tidak ada Pre-Existing Condition 
d. Full Cashless

e. Tidak ada Batasan Plafond

2) Kekurangan BPJS Kesehatan sebagai berikut :

a. Prosesnya Panjang dan Kurang Fleksibel

b. Antrian yang panjang

c. Tidak semua rumah sakit Bekerjasama dengan BPJS Kesehatan

d. Biaya rumah sakit yang tidak diganti.

c. Kelebihan dan kekurangan Asuransi Kesehatan Swasta

1) Kelebihan Asuransi Kesehatan Swasta

a. Pihak penyelenggara tidak terbatas

b. Memiliki Plafond

c. Prosesnya sangat sederhana

d. Semua rumah sakit melayani

e. Bisa digunakan di luar negeri

2) Kekurangan Asuransi Kesehatan Swasta

a. Besarnya premi tinggi

b. Kepesertaan bersifat sukarela sehingga kepesertaan sangat sedikit

c. Biaya administrasi mahal

d. Memiliki administrasi yang rumit

e. Ruang inap sangat terbatas

f. Syarat untuk memiliki asuransi kesehatan swasta sangat sulit

\section{B. SARAN}

Saran yang ditujukan untuk BPJS Kesehatan, diantaranya :

1. Memberikan informasi yang jelas mengenai sistem rujukan berjenjang,supaya masyarakat bisa paham akan peraturan BPJS yang berlaku melalui faskes tingkat 1 setelah itu baru bisa datang ke rumah sakit.

2. Memberikan penambahan untuk sosialisasi mengenai BPJS Kesehatan di daerah yang minim alat komunikasi misalnya di daerah pedesaan.

3. Sebaiknya dilakukan promosi melalui media cetak atau media elktronik untuk memperkenalkan program BPJS kepada masyarakat, khususnya tentang syarat dan iuran yang dibayarkan oleh masyarakat.

4. Meningkatkan pelayanan yang terbaik untuk masyarakat agar masyarakat tetap akan menggunakan jaminan kesehatan BPJS daripada asuransi kesehatan yang lain,sehingga keberadaan BPJS tidak akan tergeser oleh asuransi kesehatan swasta yang lain, tetapi akan berjalan beriringan untuk memberikan jaminan kesehatan yang dapat dipercaya oleh masyarakat.

\section{DAFTAR PUSTAKA}

Ali, Hasymi. dkk. (2002). Kamus Asuransi. Jakarta: Bumi Aksara. cet ke-2

Ariyanti, F. (2013). Buruh Minta Bayar Iuran BPJS Paling Rendah..Jakarta

Badan Perencanaan Pembangunan Nasional (BAPPENAS), 2002. Sistim Perlindungan dan Jaminan Sosial (Suatu Kajian awal).

Depdikbud. (1989). Kamus Besar Bahasa Indonesia. Jakarta: Balai Pustaka.

Gani, A., Thabrany, H., Pujianto, Yanuar, F., Tachman, T., Siregar, A., ... Nurbaiti. (2008). Laporan Kajian Sistem Pembiayaan Kesehatan DiBeberapa Kabupaten dan Kota Tahun 2008 (pp. 37-38). Jakarta.

Hendrartini, J. (2008). Determinan Kinerja Dokter Keluarga yang Dibayar 
Kapitasi. Jurnal Manajemen Pelayanan Kesehatan, 11(02), 77-84.

Hendrartini, J. (2010). Model Kinerja Dokter Dengan Pembayaran Kapitasi Dalam Program Asuransi Kesehatan. Disertasi. Universitas Gadjah Mada.

Iwan, Mukti, A. G., dan Riyarto, S. (2008). Evaluasi Besaran Premi Terhadap Kesesuaian Paket Pelayanan Kesehatan pada Jaminan PemeliharaanKesehatan Daerah. Jurnal Manajemen Pelayanan Kesehatan, 11(02), 49-57.

Muhammad, Abdul Kadir. (1999). Hukum Asuransi Indonesia. Bandung: Citra Aditya.

Mukti, A.G \& Moertjahjo. (2010). Program Jaminan Sosial bagi penduduk Indonesia. Yogyakarta: Universitas Gajah Mada.

Muslehudin,Muhammad. (1999). Menggugat Asuransi Modern: Mengajukan Suatu Alternatif baru dalam prespektif hukum islam.Jakarta: Lentera

Ninth Collegiete, Salim's.English- Indonesian Dictionary. Jakartra: Moder Engglis Press,t.th., Edisi Ke-1.

Rahman, Afzalur. (1996). Doktrin Ekonomi Islam.Yogyakarta: Dama Bakti Wakaf, Jilid 4.

Samba, I. G. S. (2006). Analisis Besaran Premi Jaminan Pemeliharaan Kesehatan di Kabupaten Jembrana Propinsi Bali.Tesis. Universitas Gadjah Mada.
Syahsono, Ferry E. (2010). Pengenalan Asuransi. Jakarta:Salemba Empat.

Thabrany, H.2001. Asuransi Kesehatan di Indonesia,Depok

Thabrany, H. (2011). Asuransi Kesehatan Nasional. Jakarta: FKM UI.

Undang Undang Nomor 24 Tahun 2011 tentang Badan Penyelenggara Jaminan Sosial (BPJS).

Undang Undang Nomor 40 Tahun 2004 tentang Sistem Jaminan Sosial Nasional (SJSN). 